\title{
The destruction of Jerusalem and the transmission of the Synoptic eschatological discourse
}

\author{
N H Taylor \\ Department of New Testament Studies \\ University of Pretoria
}

\begin{abstract}
This study examines the eschatological discourses in Matthew and Luke. Each is considered in its narrative context, and with detailed attention given to developments in the transmission from their common source, Mark. While both reflect awareness of historical events during the period between the composition of Mark and the time of writing, they relate to the destruction of Jerusalem and the temple very differently. While Matthew is clearly written after $70 \mathrm{CE}$, the eschatological discourse is not influenced by the events of that period. The eschatological discourse in Luke, on the other hand, has been fundamentally reshaped in the light of those events.
\end{abstract}

\section{INTRODUCTION}

There is some consensus in scholarship that Mark 13 represents the earliest extant form of the synoptic eschatological discourse. Matthew 24 and Luke 21 are essentially dependent on Mark; while the former integrates with material derived from Mark 13 the Q sayings found also in Luke 17, Luke keeps separate the eschatological material derived from Mark in chapter 21 and that from $Q$ in chapter 17. Sections of 1 Thessalonians 4, 2 Thessalonians 2, Revelation, and Didache 16 contain some of the same or similar traditions. The first and last of these make no reference to the destruction of Jerusalem and desecration of the temple, a motif in somewhat different ways central to the synoptic version of these traditions. The dating of the remaining texts is problematic, which limits 
their usefulness in reconstructing the influence of the fall of Jerusalem on the transmission of the synoptic eschatological discourses.

It is notable that none of the extant citations of the Jewish Christian and other extracanonical gospels includes any passages corresponding to the synoptic eschatological discourse. This is potentially significant, given that the Jewish Christian gospels are generally regarded as having some affinity to the synoptics, particularly Matthew. It is where these gospels diverge from the canonical gospels that they seem to have attracted particular attention from writers such as Origen, Epiphanius, and Jerome. We should therefore assume that the Gospel of the Nazoraeans, of the Hebrews, and of the Ebionites contained eschatological discourses, and that these contained no substantial deviations from the version the Jewish Christian evangelists found in Matthew. In other words, neither the Jewish uprising of 117 nor that of 132-135 CE, in particular Bar Kokhba's persecution of Christians (Orosius, 7.13.4-5), would seem to have influenced the transmission of the eschatological discourse in the Jewish Christian gospels, at least not in ways which the Church Fathers found remarkable.

In view of the above, this study can concentrate on canonical material, in particular developments between Mark and the later synoptic evangelists Matthew and Luke. There is a clear consensus in scholarship that the canonical versions of both later gospels date from after $70 \mathrm{CE}$, even if an earlier version of Luke may have dated from sometime earlier, say C. $62 \mathrm{CE}$, the point at which the Acts narrative concludes. The first question therefore concerns the date of Mark, and therefore whether developments in the tradition from Mark to Matthew and Luke can be attributed to Christian reflection on the events of $70 \mathrm{CE}$. A distinction needs to be drawn between the date of composition of the canonical gospel on the one hand, and, on the other, the date when the eschatological discourse in chapter 13 was first circulated. It is the latter which is of immediate concern, even though the canonical version would presumably have been that known to and used by Matthew and Luke. 
I have argued previously that the defining influence on the eschatological discourse in Mark 13 was the project of the emperor Gaius Caligula to have his statue erected in the temple in Jerusalem in $40 \mathrm{CE}$, and that this text was shaped by Christian reflection on the crisis in Judaea and its immediate aftermath (Taylor 1996a, 1996b). ${ }^{1}$ The reasons for this dating can be summarised as follows: 1 ) the historical circumstances and events alluded to in Mark 13:5-9, 11-13 can all be attested in the eastern Mediterranean region, or reliably hypothesised in the experience of Christians in Judaea, during the period immediately prior to $40 \mathrm{CE}$ and culminating in the expectation of the desecration of the temple by Roman forces installing Caligula's statue; 2) the description of events in Mark 13:14-19 is incompatible with the course of events in and around Jerusalem during the closing stages of the war of 66-70 CE, at least as recounted by Josephus (BJ 6.130-7.4), but compatible with the situation, real or anticipated, of Christians in Jerusalem in $40 \mathrm{CE} ; 3$ ) the Daniel passages cited refer to desecration of the temple through the imposition of a pagan imperial cult, not to the destruction of

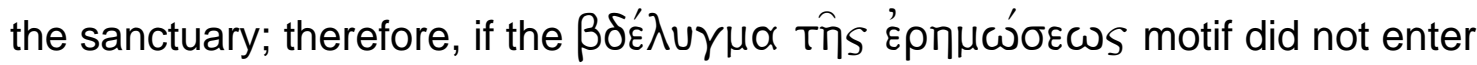
the tradition at this time, those passages would not have been amenable to reinterpretation in the light of the events of $70 \mathrm{CE}$; 4) the prophecy of the destruction of the temple in Mark 13:1-2 is never explicitly fulfilled in the subsequent eschatological discourse, which suggests that it may not have been fulfilled at the time of writing; 5) the transition from present to future tense at Mark 13:20 presupposes that the temple is still standing; 6 ) the climax of the discourse in Mark 13:24-27 envisages a cosmic rather than terrestrial phenomenon, which would presumably include the destruction of the temple at the future coming of the Son of Man.

Arguments for the date of composition of Mark as a whole are rather more complex. This issue is of secondary importance for the present purpose, but

${ }^{1}$ The most significant challenge to this thesis is the work of Such (1999). While a forceful defence of a post- 70 date for Mark, I remain persuaded that an earlier date is required; cf my review in Neot 33 (1999) 266. Balabanski (1997:89-129) has argued that the eschatological discourse, including the allusion to the desolating sacrilege, has no connection with the events of $40 \mathrm{CE}$. 
account must be taken of the possibility of development in the tradition between the composition of the eschatological discourse and its incorporation in what is now the canonical gospel of Mark. Once the existence of earlier textual units is recognised, use can no longer be made of the tradition of Papias associating the gospel with Peter, and dating it to the period after his death (Eusebius, HE 3.49.15-16). Irrespective of the identity of Mark, the connection with Peter can at the most account for only some of the material contained in the canonical gospel. The eschatological discourse is not the only section for which an early date is likely. I have argued elsewhere that the section Mark 2:1-3:6 as well as other smaller units must be dated to approximately the same period, viz. the reign of Agrippa I (Taylor 2000b; cf Hultgren 1979). Theissen and Crossan have argued that the Passion Narrative, or what Crossan calls the Cross Gospel, dates from the same period (Theissen 1991; Crossan 1988; 1998). This would seem the most likely occasion on which blame for the death of Jesus came to be transferred from Roman to Jewish rulers, and on which the Herodian family would have acquired such responsibility (cf Taylor 2000b; 2001b). This indicates a date for an oral or written form of the Passion Narrative in the first decade of Christianity. The sayings on ritual purity and dietary observance in Mark 7 envisage an intra-Jewish debate in Palestine rather than a diaspora or missionary context in which gentile Christians are present, which suggests a date before Palestinian Christians needed to concern themselves with such issues (Dunn 1990; cf Räisänen 1992; Taylor 2003a). The saying in Mark 9:1, if not dominical, clearly dates from a period before it was falsified through the passing of time; even if juxtaposition of the transfiguration story reflects a reinterpretation thereof, this would have been necessary before the end of the third decade of Christianity at the latest (pace, Meier 1994:341-44). ${ }^{2}$ Other pericopae in Mark can less easily be dated with any precision, but there is no indication of any influence of the events of 66-70 CE or later on the tradition. A date for canonical

\footnotetext{
${ }^{2}$ For discussion of life expectancy during this period see Blenkinsopp 1997; Malina \& Rohrbaugh
} 1991. 
Mark during the period not later than c. 60-64 CE will therefore be presupposed for the purposes of this study.

Before addressing the central question, some comments on the interrelationship of oral and scribal traditions in the synoptic gospels would be helpful. While some diversity in the tradition may be attributable to the frequency with Jesus imparted the same material on different occasions (Wright 1992), it needs also to be recognised that oral traditions develop and bifurcate, and therefore some reflect earlier stages in the transmission than others, even if it is not always possible to be certain which (cf Allison 1998). Oral traditions do not cease to function once a written text has been produced (cf Crossan 1998). Only where a text is found in isolation from the context in which it was produced, and forms the basis of a new text, is it possible to exclude oral traditions from influencing the transmission and redaction processes. It is unlikely that any early Christian text originates in a context in which oral Jesus traditions were not being transmitted, interpreted, and expounded. Therefore, while Mark and (a written) Q will be regarded, for the present purpose, as the foundation documents of Matthew and Luke, this does not exclude the possibility that oral traditions influenced the reception and interpretation of these documents, and accordingly the ways in which they were used, together with other written sources, in the composition of Matthew and Luke. It cannot be assumed that written sources would have been more highly valued than oral traditions, or have been regarded as more reliable. On the contrary, the example of Papias (cited by Eusebius, HE 3.49.15-16) indicates that the opposite could have been the case, and that documentary sources would have been corrected in the light of oral traditions, not least in the composition of Matthew and Luke.

\section{THE ESCHATOLOGICAL DISCOURSE IN MATTHEW}

There is a broad consensus in scholarship that Matthew was written some years after 70 CE (Beare 1981:7-12; Davies \& Allison 1988:127-38; Filson 1960:10-16; Schweizer 1975:15-17; Stanton 1992:157-68; contra, Reicke 1972; Robinson 1976). The influence of the destruction of Jerusalem on the redaction of Matthew 


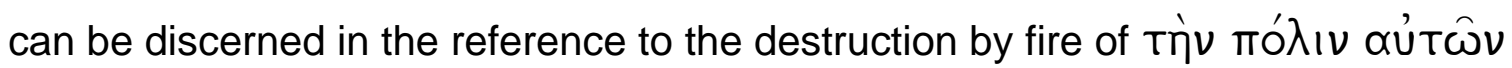
in 22:7 (cf Josephus, BJ 6.353-404; 2 Bar 7:1; 80:3; SibOr 4.125-27). "[T]his is the single verse in the New Testament that most looks like a retrospective prophecy of the events of 70" (Robinson 1976:20). This observation will be seen to be significant when we come to examine the transmission of the eschatological discourse in Matthew.

The eschatological discourse is drawn largely from Mark 13, incorporating some material from $\mathrm{Q}$ and another source akin to Didache 16 . It is placed in the centre of Jesus' fifth and final major discourse in Matthew 23-25. This begins in the temple, which Jesus and his disciples vacate for the last time at 24:1. Despite the shift of location from the temple to the Mount of Olives, there is some degree of continuity through the discourse. However, as we are dealing with the transmission of the traditions contained in Mark 13, we can focus our attention on chapter 24 of Matthew. The surrounding text need be considered only insofar as it impinges on our central question.

Matthew 23 concludes with the juxtaposition of two Q sayings, which Luke transmits separately, and in the reverse order, at 11:49-51 and 13:34-35. Whereas in Luke, and presumably in $\mathrm{Q}$, the reference to the temple in the latter text is ambiguous but probable (Taylor 1999b:714), in Mt 23:35 the use of voós where Luke uses oîkos makes more probable that the temple in which Zechariah was murdered is also the house that would be left desolate (cf Davies \& Allison 1997:321-22). The temple is abandoned by God for destruction, as a consequence of the murder of the prophets (Beare 1981:462; Davies \& Allison 1997:322). There is no reference to fire in this text, which indicates that its transmission and redaction have not been influenced by the historical event (Beare 1981: 462). The identification of the Zechariah through a patronym vioû Bapaxíou absent from Luke and presumably from $Q$ could possibly reflect late emendation of the tradition, and refer to the incident related by Josephus in $B J$ 4.334-44. If this were the case, Jesus would be portrayed as prophesying an event which would take place several decades after his historical ministry 
(Origen, In Mt fr 457; cf Chrysostom, In Mt 74:2). However, it is much more likely that Matthew is referring to Zechariah the priest murdered in the temple in $2 \mathrm{Chr}$ 24:21, conflated with the canonical prophet and substituting his patronym (Davies \& Allison 1997:319). This may be supported by the corresponding text in the Gospel of the Nazoraeans, which identifies Zechariah as the son of Joiada (Jerome, In Mt 23:35). Jesus is therefore referring to the first and last murders recorded in the Tanakh. The two Q passages are linked through the theme of murder of the prophets, for which the destruction of the temple is an act of divine

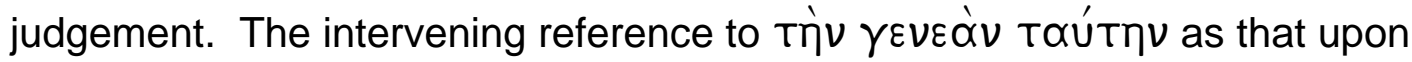
which divine judgement would be meted out (Mt 23:36), closely juxtaposed to the

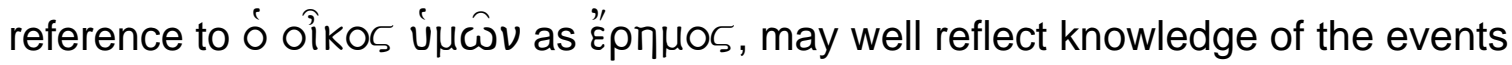
of $70 \mathrm{CE}$. What is significant, however, is that in Matthew Jesus makes an unequivocal pronouncement of judgement and destruction on the temple before, and not as a response to, the disciples' comment on the scale and grandeur of

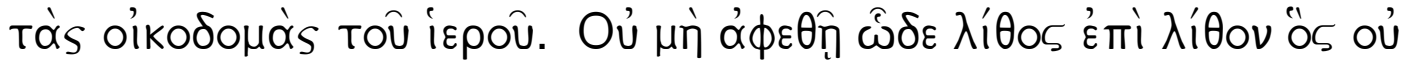
$\kappa \propto \tau \alpha \lambda \cup \theta \eta \dot{\sigma \varepsilon \tau} \propto$ । (24:2) therefore confirms a judgement of destruction which has already been pronounced.

A major development from Mark lies in the question posed to Jesus by the disciples, which provides the narrative pretext for the eschatological discourse. As well as asking when the events Jesus had just foretold would take place (Mk

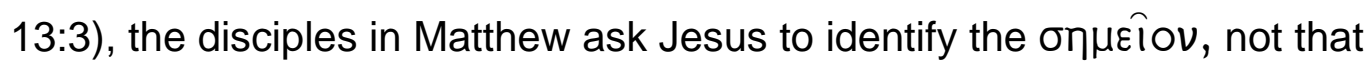
fulfilment of the preceding prophecies was imminent, but the $\sigma \eta \mu \varepsilon \hat{\imath} \mathrm{V}$ of his

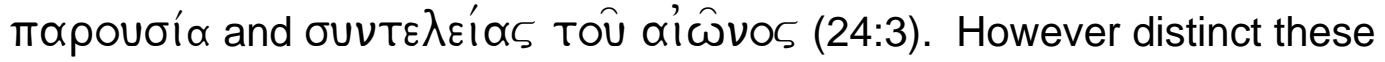
events may be (Beare 1981:464), the destruction of the temple can be equated with neither, and the disciples expect them to be announced by the same signal. While, for as long as the temple stood, Christians must have expected its destruction as foretold by Jesus (Mk 13:2; cf 11:15-17; Taylor 1999c; 1999d), this is not the event awaited by Jesus' disciples in Matthew. Irrespective of whether the rephrasing of the question is a response to the fall of Jerusalem, for Matthew the destruction of the temple has ceased to be a defining eschatological sign. 
Whereas for Mark the destruction of the temple is subsumed in a cosmic eschatological event, and not equated with its desecration (Taylor 1996b), for Matthew the question of importance is that cosmic eschatological event, not any terrestrial precursor (cf Davies \& Allison 1997:337; pace, Balabanski 1997:129).

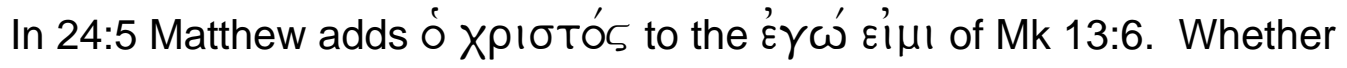
this qualification is to avoid association with the divine name, or to provide clarification, it is clear that messianic claimants are in view. It is more likely that this refers to non-Christian Jewish figures than to Christians claiming to speak with Jesus' voice and, by implication, authority (cf Boring 1991; Crossan 1998; Davies \& Allison 1998:338-39). It is the title and office of Jesus that are usurped, from a Christian perspective, not the person. It is possible that Matthew has emended the tradition in the light of messianic claimants active during the war of 66-70 CE, such as Menahem (BJ 2.422-42) and Simon bar Giora (BJ 2.521,65253 ; 4.503-13,529-34,574-8; 5.309,421,530-33), in which case this aspect of Jesus' prophecy is understood by the evangelist to have been fulfilled. However, it is also possible that Matthew is simply observing Jewish sensibilities, and avoiding connotations of the divine name (Davies \& Allison 1997:339).

Matthew transmits Mk 13:9-13 not in the eschatological discourse but at $10: 17-22$, in the context of the charge to the disciples, before they are despatched on a mission to Israel during the historical ministry of Jesus. The experiences of persecution and betrayal are no longer a matter of eschatological expectation, except insofar as the period of the evangelist is by implication located between the historical ministry of Jesus and his awaited return. Persecution belongs to the present experience of Christians, from the time of Jesus' historical ministry onwards, and is not a future expectation. This was part of the experience of Christians in Palestine and elsewhere well before the fall of Jerusalem (Jewett 1971; Reicke 1984; Taylor 1996a; 2001b; 2002), and this development in the transmission of the tradition in no way reflects or presupposes any influence by the events of 66-70 CE.

In place of Mk 13:9-13 Matthew incorporates at 24:10-12 material derived from another source. The similarity of this to material contained in Did 16:3-6 
indicates a common source (cf Davies \& Allison 1997:337; Niederwimmer 1998:42-52, 207-27). The content is not dissimilar to that which it replaces either, and it is likely that some redactional phrases $(24: 9,13,14)$ are used to join the texts. The level of persecution alluded to is heightened, in that Jesus

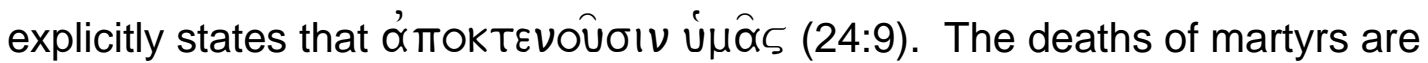
attested in Jerusalem from an early date (Taylor 2001b, 2003b), and Paul at least was no stranger to the threat of violent death in other places (cf 1 Cor 15:32). Irrespective of where Matthew is to be located, deaths in his immediate community are not presupposed. Knowledge of the martyrdoms of prominent Christians such as Peter and James son of Zebedee, named as recipients of the eschatological discourse in Mark (cf Jn 21:18-19; Ac 12:1-3), and James the brother of Jesus (AJ 20.200-202), would be sufficient to warrant reference to death at this point. The reference to apostasy (24:10) reflects a phenomenon probably as widespread as martyrdom, and undoubtedly often induced by the same persecution as well as by the activities of $\psi \varepsilon \cup \delta \circ \pi \rho \circ \phi \hat{\eta} \tau \propto l ~(24: 11)$. The historical experience of Christian communities during the first century would undoubtedly have included such events in many places and on numerous occasions (cf 1 Thess 2:13-16; Jewett 1971; Reicke 1984; Taylor 1996a; 2001b; 2002), and these allusions do not presuppose the situation of the war of 66-70 CE in Palestine or its impact on Jewish communities elsewhere in the Roman empire.

Matthew gives greater emphasis than Mark to the imperative to proclaim the gospel to the gentiles before Tò T'́x perhaps arguable that this conviction is born of the failure of Christian parousia hopes when Jerusalem was destroyed in 70 CE. However, irrespective of Matthew's opinion of Paul, the missionary drive in Christianity had been under way for several decades, born, I have argued previously, of the failure of parousia hopes in the aftermath of the Caligula crisis in 40-41 CE (Taylor 2000a). The events of 70 CE would no more than have confirmed what was already a well established conviction in at least some Christian communities well before this date. Furthermore, the expectation of the eschatological conversion of the 
gentiles had been established in the Jewish prophetic tradition for centuries (Is 2:2-4; 45:20-22; 49:6; 55:5; 56:6-8; Mc 4:1-3; 1 En 48:4-5; T Lv 18:5-9; SibOr 3:710-23; cf Martin-Achard 1962; McKnight 1991; Sanders 1985). What was different was the missionary drive to bring this about, an activity which Matthew at least believed the Pharisees as well as Christians to undertake (23:15), rather than awaiting divine action to bring about the eschatological conversion of the gentiles (cf Cohen 1989; Goodman 1994). Any Jewish community with a sense of eschatological urgency, and which revered the prophets as Scripture, could conceivably have sought to hasten divine action through bringing to fulfilment eschatological prophecies such as these. This certainly did not begin with the Christians after $70 \mathrm{CE}$, and, even if some Jewish Christian groups continued to rely on divine action, others were active in mission to gentiles decades before the outbreak of war in $66 \mathrm{CE}$. The fall of Jerusalem could therefore have no more than confirmed what was already an established Christian conviction and practice.

The climax (Haenchen 1968:444; Theissen 1991:159-60) of the eschatological discourse, so far as Jesus' response to the disciples in Mark is concerned, is fundamentally unaltered in Matthew. The same phrase tò

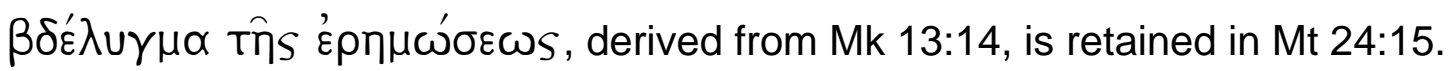
The implicit reference to its location in the temple in Mark becomes explicit in

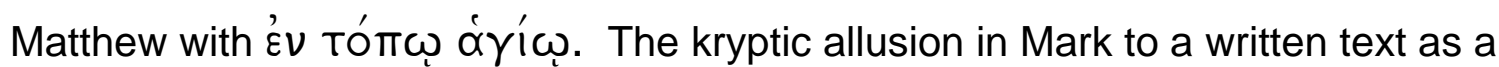
clue to interpretation becomes in Matthew an explicit citation of Daniel as prophecy to be fulfilled. We should assume that the evangelist understands all three Daniel texts $(9: 27 ; 11: 31 ; 12: 11)$ to be fulfilled through the events to which he is alluding, rather than one specific occurrence, even though Dan 12:11 LXX is the only one with which Mt 24:15 is in verbal agreement. ${ }^{3}$ There is no doubt that Mark is quite consciously alluding to Daniel (Taylor 1996b), and therefore no substantial development in the interpretation of the tradition between Mark and Matthew. There is in any event no likelihood that the more overt citation of

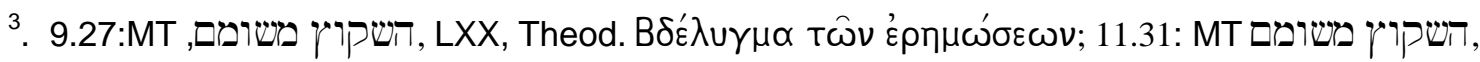

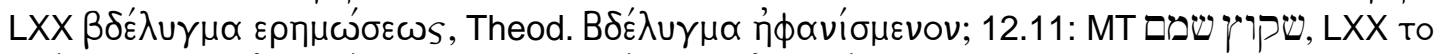

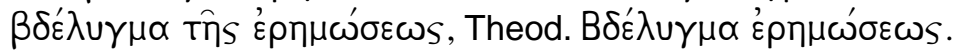


Daniel is influenced by the events of $70 \mathrm{CE}$. If anything, it is more likely that this development took place before the temple was destroyed, as all three verses in Daniel refer quite clearly to the forcible cessation of the cult and the establishment of a sacrilegious object and cult in the temple, and none makes any suggestion that the building would be destroyed. Dn 9:27 and 12:11 both indicate that this profanation of the temple would be the final precursor to God's eschatological intervention, and the latter text suggests that this would take place within a period of four years. Therefore, even if the supplanting of the established cult with an idolatrous one has come to be reinterpreted as destruction of the shrine in which the cult is practised, ${ }^{4}$ unless Matthew was written within four years of the destruction of the temple, any influence of that event on the transmission and redaction of the tradition must be excluded.

Rather, it should be assumed that scribal and possibly apocalyptic interests led to the more explicit citation of Daniel, and not any perceived fulfilment in the events of $70 \mathrm{CE}$. It is, furthermore, far from clear that Matthew regards this prophecy as already having been fulfilled, or whether, like Mark, he still expects this to take place (cf 2 Th 2:3-4; cf Davies \& Allison 1997:345-46).

To Jesus' injunction in Mk 13:18 to the disciples to pray that the sign to flee Jerusalem and its environs would not be manifested in winter, Matthew adds at 24:20 $\mu \eta \delta^{\prime} \varepsilon \alpha \beta \beta \alpha \alpha^{\prime} \omega \omega$. This indicates that for Matthew and the community whose ethos the evangelist reflects questions of sabbath observance could raise scruples about a journey to a safe destination. This suggests rejection of the halakhah attributed to Mattathias in 1 Mac 2:41, in the light of the massacre reported in 2:32-38, in terms of which at least defensive action on the sabbath was deemed permissible. Davies and Allison argue that this insertion by Matthew presupposes that the occasion of flight was still perceived to lie in the future at the time of writing, or an injunction to prayer would be meaningless (1997:349). However, the injunction to prayer is in the received tradition (Mk 13:18), and is not redactional. The evangelist and Christian Jews living outside

\footnotetext{
${ }^{4}$ Josephus does record cultic activities in the temple court by Titus' troops (BJ 6.316), but these would surely pale into insignificance compared with the destruction of city and temple which were already under way.
} 
Palestine would not necessarily have known at what precise time of year Jerusalem was finally overrun, still less the day of the week. To a sabbath observant Christian Jew it could have been entirely logical to suppose that Jesus would have been concerned about the constraints placed on flight by the fourth commandment (Ex 20:8-11) as well as about hazards of travel in winter weather. There is nevertheless no reason to see influence of the events of $70 \mathrm{CE}$ on this tradition. Not only would there have been no opportunity to flee by the time the Roman troops had entered the temple precincts (cf Taylor 1996b), but, even if there were, it would have required more than a single day, or even the days before the commencement of the next sabbath, to escape capture and enslavement or death at the hands of the Romans, even at the most opportune time of year. Irrespective of whether Matthew knew on what day of the week on which Titus entered Jerusalem and his troops set fire to the temple, this section of the eschatological discourse betrays no influence on the tradition by retrospection on those events.

Mt 24:26 would seem to be redactional, influenced by $\mathrm{Q}$ 17:23 and Mk 13:21, which is also transmitted at 24:23. Matthew mentions two specific places of potential manifestation of false messiahs. Their possible appearance $\varepsilon v+\underline{v}$ દ̊ń $\mu \omega$ reflects not merely a traditional motif (Is 40:3; cf Jn 6:15; 1QS 8:12-14; 9:19-20), but a well documented occurrence during the first century (Ac 21:38; $B \mathrm{~J}$ 2:258-63; AJ 20:167-72, 188). It is entirely possible that the evangelist is responding to known events of the period. These, however, took place before rather than during or after the war of 66-70 CE, and would not have entered the tradition under the influence of that war. Manifestation, or rather clandestine

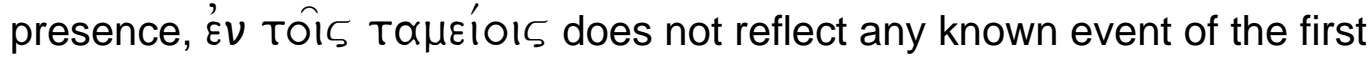
century, with the possible exception of Simon bar Giora's concealment and then dramatic appearance in the temple after the Roman occupation thereof, which led to his capture and ultimately execution in Rome at the conclusion of Vespasian and Titus's triumphal procession (BJ 7.26-36). However, the emphasis in Josephus's account is on Simon's dramatic appearance, not any clandestine messianic activities before his self-manifestation. On the contrary, 
his activities hitherto had been public, and his concealment was for dramatic effect when the Romans took the temple, as well as fulfilment of expectations that the temple would be the place where the messiah was manifested. While there was almost certainly some hope or expectation of messianic delivery during the final stages of the siege of Jerusalem, whether Christians would have identified with such sentiments is another matter (Taylor 1999c, 1999d).

Mt 24:27, 28 derive from Q 17:24, 37, and Matthew then returns to the markan text, incorporating Mk 13:24-25 at 24:29. Mt 24:30 combines Q 17:30

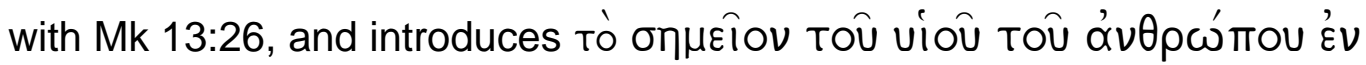

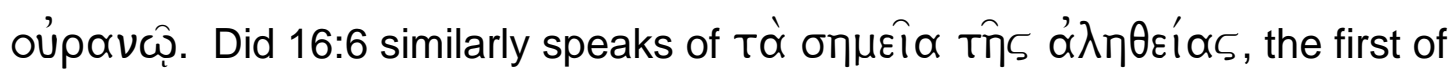
which is the opening of heaven ( $\mathrm{cf} A \mathrm{c} 7: 56$ ), presumably the prerequisite to the manifestation of the returning Christ. The second sign in Didache 16 is the sound of the trumpet (cf Mt 24:31; 1 Th 4:16), and the third the resurrection of the dead (cf Mt 24:31; 1 Th 4:16-17). The second and third signs will be discussed shortly, corresponding as they do to phenomena related in the subsequent verse.

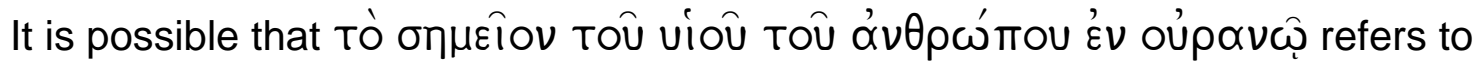
the opening of heaven, allowing Christ the Son of Man to descend for the events that are to follow. In this case, the opening is not merely a practical prerequisite to the manifestation and parousia of Christ, but the signal that this is about to

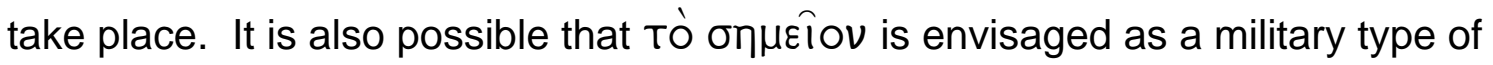
image or standard, analogous to those of the Roman units who occupied Palestine (cf Draper 1993). It is entirely possible that this standard could have been envisaged as taking the form of a cross (cf GPet 10:39-42; ApocPet 1; cf Gaston 1970:484-86), but this is by no means certain (cf Davies \& Allison 1997:359). It is possible that military imagery, both the standard in this verse and the trumpet in the next, may have been introduced to the tradition under the influence of the war of 66-70 CE. However, such imagery was by no means new to conceptualisations of God's eschatological intervention in the world (Dn 10:21; $12: 1 ; 1 \mathrm{QS})$, and is present in as early a Christian text as 1 Thessalonians, written up to two decades before $70 \mathrm{CE}$. There is no suggestion that Christians should or would participate in the eschatological war, but there is the expectation that 
the defeat of God's enemies would result in deaths which would occasion

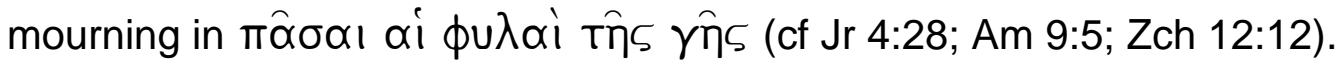

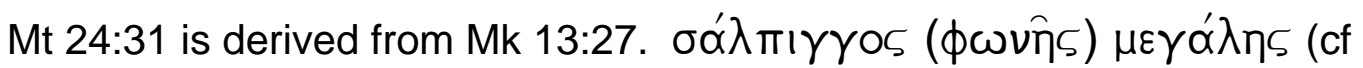
1 Th 4:16; Did 16:6) is clearly a military type signal to the angels, but, as with tò

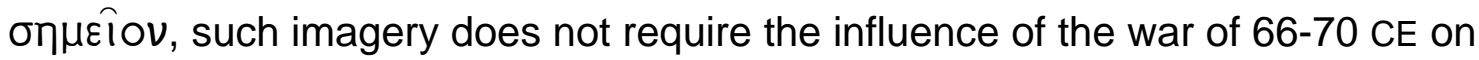
the tradition, but was already a well established apocalyptic motif. It is, furthermore, integral to the eschatological vocabulary Paul employs a decade

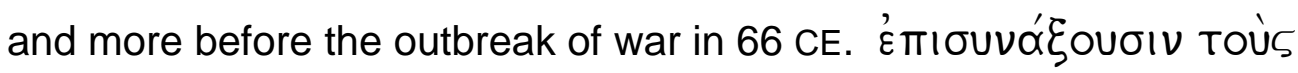

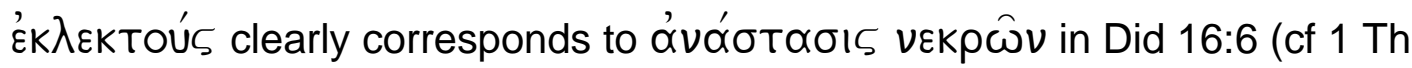
4:16-17), an expectation central and fundamental to early Christian belief (Taylor 1999c). The corresponding sequence of eschatological motifs suggests that Matthew and Didache draw upon a common tradition at this point (Niderwimmer 1998:223-24), one which may also have influenced Paul in 1 Th 4:13-18. The war of 66-70 CE cannot account for the introduction of the military motifs to the tradition, even if the experience of war gave them an air of verisimilitude.

The concluding verses of Matthew's eschatological discourse derive from Mark (13:28-32 in Mt 24:32-36) and Q (17:26-27 in Mt 24:37-39; 17:34-35 in Mt 24:40-41; cf GThos 61). The final injunction to vigilance derives from Mk 13:3237 and Q 12:35-40, and reflects a motif widespread in early Christian literature (1 Th 5:2; 2 Pet 3:10; Rv 16:15; Did 16:1; GThos 21; 103). The conflation of traditions into a single discourse by the redactor is evident, but there is no indication at all that the war of 66-70 CE influenced this process.

In conclusion, therefore, while Matthew demonstrates awareness of the destruction of Jerusalem in 70 CE (22:7), and confidence that Jesus' prophecy against the temple would be effected (23:35-38), the eschatological discourse itself reflects no influence at all of these events upon the transmission of the tradition. Developments between Mark and Matthew can be accounted for principally by the incorporation of material from $\mathrm{Q}$ and the eschatological tradition reflected also in 1 Thessalonians and the Didache. The destruction of the temple has ceased to be the crucial moment in Matthew's eschatological expectations, 
but his focus has shifted to the return of Christ and the end of the age. This has been accomplished without alteration to the eschatological discourse itself, but only to the question posed by the disciples at the beginning. This is possible partly because Mark has already distanced terrestrial events in the temple from the cosmic events which define the ultimate eschatological moment (Taylor 1996b). However, it needs also to be noted that the temple had ceased to be the locus of Christian eschatological hopes at an early date, and was relevant only as an institution upon which Jesus had pronounced judgement. Its destruction was fulfilment, but not in itself a moment of eschatological ultimacy.

\section{THE ESCHATOLOGICAL DISCOURSE IN LUKE}

The majority of scholars believe that Luke was written some years after the fall of Jerusalem, and probably in an urban centre of the eastern Mediterranean region outside Palestine (Bacon 1925:66-67; C A Evans 1990:2; C F Evans 1990:13-15; Fitzmyer 1979:53-57; Schweizer 1984:6; Streeter 1930:494; cf Hartman 1966:244-45; Marshall 1978:33-35; Nolland 1989:xxxvii-xxxix). A minority maintain an earlier date (Reicke 1972; Robinson 1976), and some argue that an earlier version, commonly known as proto-Luke, was in circulation prior to the canonical redaction (Gaston 1970:244-56; Streeter 1930:233-70; Taylor 1926). If either of the latter is correct, then any influence of the events of $70 \mathrm{CE}$ on the tradition is a priori excluded. However, if the majority position is correct, then the influence of the fall of Jerusalem and destruction of the temple on the transmission of the eschatological discourse in Luke needs to be established.

As noted above, Luke includes two eschatological discourses. The first is derived from $\mathrm{Q}$, and consists of thematically related but schematically unconnected sayings (17:22-37; cf Horsley \& Draper 1999). This is delivered

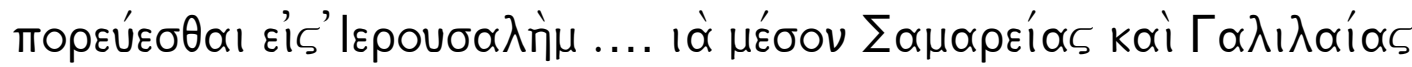
(17:11), in the so-called travel narrative, but well before Jesus and his disciples reach the vicinity of Jerusalem. The second (21:7-36) is derived principally from Mark 13, and is that to which attention is now required. Like Matthew, Luke places this in the context of a longer teaching section (19:47-21:38), located in 
the temple court and addressed to a broader group of interlocutors than Jesus' disciples. The Lukan transmission of the tradition raises crucial questions concerning the significance of the destruction of Jerusalem and the temple for Christians of the period, particularly the gentile Christians and potential sympathisers addressed by the gospel, who lived outside Palestine and presumably had had little if any connection with Jewish institutions including the temple (cf Taylor 1999b).

Jesus' first pronouncement of destruction on Jerusalem is located not in the city itself or its environs, but somewhere in the territory of Antipas, i e in Galilee or, less likely (cf 17:11), Peraea (13:31), en route for Jerusalem (13:22). The Q saying preserved in Lk 13:34-35 precedes Jesus' arrival in Jerusalem for the first time since the infancy narratives (2:22-38,41-50), and is therefore not a response to conditions he discovers in the city and temple (Taylor 1999b). While it may be debatable whether this text refers to the temple, or to the city as a whole, or even to the dynasty associated with Jerusalem (cf Baltzer 1965), any reference to the city would surely include the temple. A Davidic reference is highly unlikely, given that the dynasty had been defunct for centuries, and there is no attempt to relate this to the recurring theme of the davidic descent of Jesus (cf Lk 1:27, 32; $2: 4 ; 3: 31 ; 18: 38-39 ; 20: 41-44$ ). There is also no indication that the house of Annas was associated with Jerusalem in such a way that there could be any allusion to its final demise under the Zealots during the early stages of the war of 66-70 CE (BJ 4.151-55). It is therefore most likely that this text refers to the temple, but possibly to the city of Jerusalem as a whole.

The second pronouncement of judgement on Jerusalem also precedes Jesus' arrival in the city (19:41-44), and is located presumably on the Mount of Olives as Jesus and his disciples approach Jerusalem (cf Fitzmyer 1985:1257). The saying is generally ascribed to tradition unique to Luke $(L)$, as well as to $M k$ 13:2, rather than to the redactor (cf Fitzmyer 1985:1253). The prediction of destruction in 19:44 refers to the city as a whole, rather than to the temple in particular as in Mk 13:2. The explicit military imagery, of a siege followed by the massacre of the inhabitants of the city, leads the majority of scholars to believe 
that the tradition has been modified in the light of the events of $70 \mathrm{CE}$ when the Roman forces took Jerusalem (C F Evans 1990:685; Fitzmyer 1985:1253-55). Other scholars argue that the influence upon the tradition is derived not from the siege and destruction of Jerusalem by the Romans in $70 \mathrm{CE}$, but by LXX accounts of the destruction of Jerusalem by the Babylonians in $587 \mathrm{BCE}$ (Dodd 1947; cf C A Evans 1990:290,294-95). This issue will be considered in detail below, when Lk 21:20-24 is discussed. For the present, however, we must note that the issue which divides scholars is crucial to establishing whether or not Christian beliefs and expectations were significantly affected by the fall of Jerusalem.

The eschatological discourse is located in the temple court, and not on the Mount of Olives as in Mark and Matthew. The comments which precipitate Jesus' pronouncement of destruction (21:6) are not attributed to the disciples, and concern not so much the scale as the adornment of the temple buildings (21:5). This section nevertheless derives from Mk 13:1-2, with changes reflecting the different context and location in which Luke places the narrative. The question posed in response to Jesus' pronouncement, like the preceding comment, is attributed not to the disciples but to Jesus' audience in more general terms (21:7). The questions refer quite specifically to the destruction of the

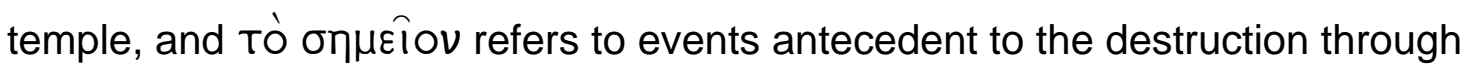

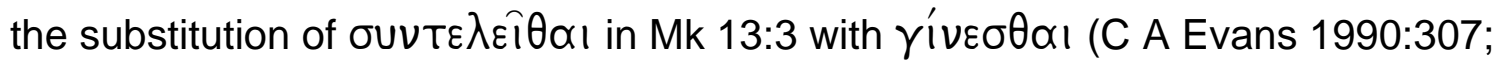
C F Evans 1990:736; Fitzmyer 1985:1327). Jesus' response is public discourse rather than secret or esoteric teaching to his disciples.

Jesus' eschatological speech is derived substantially from Mark 13 in its basic structure, with scholars debating whether mutations in the transmission are attributable to a second source (C A Evans 1990:312; Fitzmyer 1985:1326; Gaston 1970; Hartman 1966:228-34) or are redactional (C F Evans 1990:732). Note should also be taken of the position of Manson (1957:328-331), who argues that the version preserved in Luke is ancient, dating from the first decade of Christianity, and that Mark adapted the tradition in the light of events under Caligula in 40-41 CE. Were this to be correct, we would have preserved in Luke 
a pre-Markan tradition which would be very ancient indeed and arguably very close to the eschatological teaching of Jesus. However, the events envisaged in Lk 21:20-24 are clearly terrestrial, even if inspired largely by prophetic passages in the Tanakh (cf Dodd 1947), and do not envisage direct divine intervention on a local or cosmic scale. Eschatological teaching attributed to Jesus outside the eschatological discourse tends towards cosmic events (cf Lk 17:24), and this would seem to be corroborated by the supernatural overtones to accounts of Jesus' pronouncement of judgement against the temple in the passion narrative (Mk 14:58; 15:29; cf Jn 2:19; PsSol 17). It would therefore seem more likely that Luke 21 reflects historicisation of Jesus' teaching and the markan transmission thereof than that it represents a more ancient form of that tradition.

Jesus' initial warning (21:8) is substantially as in Mk 13:4. The claim of the pretenders remains the enigmatic $\varepsilon \gamma \omega \dot{~ \varepsilon i \mu l, ~ r a t h e r ~ t h a n ~ t h e ~ m o r e ~ s p e c i f i c ~}$ christological claim in Mt 24:5. Fitzmyer (1985:1338) interprets this to mean a claim to be Jesus rather than as a non-Christian messianic claim. If Luke is addressed to gentile readers and hearers unlikely to be alert to innuendoes derived from Hebrew Scripture, then it is entirely possible that the evangelist avoids phraseology meaningful only in terms of Scripture. However, Luke does in places expect that at least some readers would appreciate allusions to the biblical tradition. Nevertheless, while his non-Jewish readership may account for

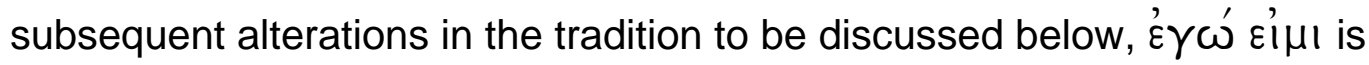
retained in Lk 21:8, and is meaningful, in the sense of being christological or otherwise theologically significant, only with a mutually understood point of reference. It is perhaps simply the unlikelihood that Jewish messianic claimants would emerge in diaspora settings, and therefore that they would pose any threat to the allegiance of gentile Christians, that accounts for the wording of the text at

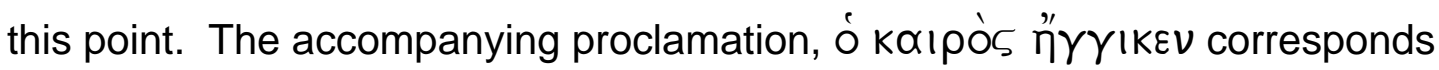
with the summary of Jesus' teaching in Mk 1:14-15 and Mt 4:17, but this expression is missing from Lk 4:14-15 (but cf 10:9), arguably replaced by the account of Jesus' preaching in the synagogue at Nazareth, with its theme of the fulfilment of Isa 61:1-2 (4:16-30). It cannot therefore serve in the lukan narrative 
as a means of identifying a claimant to be Jesus, or, for that matter, to continuity with John the Baptist (cf Mt 3:1-2) and Jesus. The claim is clearly one to eschatological significance, and the omission of the warning not to be deluded could indicate that Christians had in fact stood firm against such claims by the time the gospel was written (cf C F Evans 1990:738). If Luke is addressed to a diaspora setting, then the original readers and hearers may not have experienced the same pressures as Palestinian Christians, not merely during the war of 66-70 CE but during the preceding decades also (cf Jewett 1971; Reicke 1984; Taylor 1996a, 2001a, 2001b). ${ }^{5}$

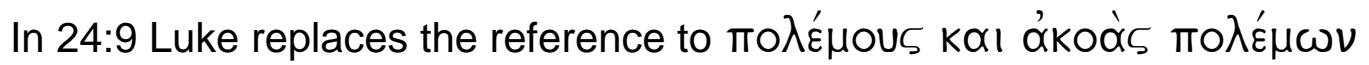

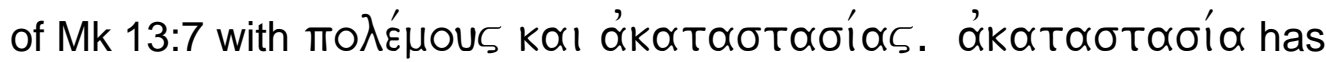
connotations of political disturbance (C F Evans 1990:739), and could allude specifically to the various uprisings against Nero and his successors in Rome during the late 60's CE (BJ 4.491-96,546-8,592-605,616-22,630-55; Suet, Nero 47-49; Galba 19-20; Otho 8-11; Vit 9-18; Tac, Hist 2.41-49,83-86; 3.13-84), or be a pejorative reference to the Jewish uprising against Roman rule in $66 \mathrm{CE}$ (cf Fitzmyer 1985:1338). If the reference is this specific, then the evangelist is concerned that these events should not be attributed eschatological significance, except as preliminary stages in a larger and longer scheme. The emphasis of

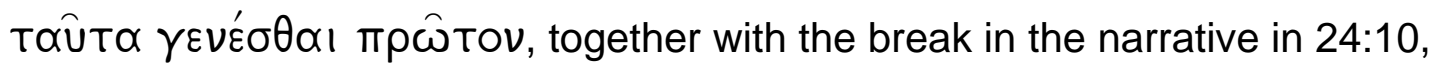
serve to distinguish events already in the experience of Christians at the time the gospel was written from events of immediate eschatological significance in the future.

To the natural disasters of Mk 13:8 Luke adds $\lambda$ oı $\mu$ oi in 24:11. Rather than alluding to an outbreak of disease, in itself not an unlikely phenomenon in an ancient city, especially one under siege, scholars tend to view this insertion as

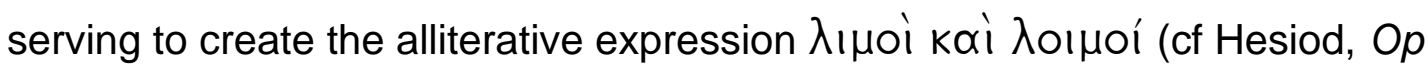

\footnotetext{
${ }^{5}$ Cf 1 Th 2:13-16 (see Taylor 2002). The experience of the Pauline congregation in Thessalonica may not have been replicated in other centres, as the theme of persecution is less prominent in other Pauline letters than in later documents such as 1 Peter and Revelation. Still less would the experience of Paul himself, reflected in 2 Cor 11:22-32, have been representative of all Christians of this period.
} 
243; Thucydides, Hist 2.5.4; T Jud 23:3; SibOr 8.175; cf C F Evans 1990:740; Fitzmyer 1985:1337; Marshall 1978:765; Nolland 1993:992). The two words

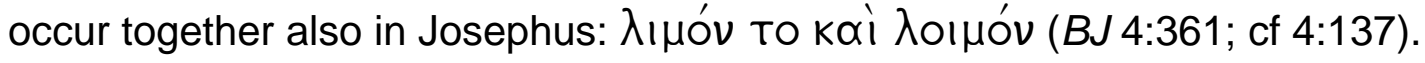
The context of the in-fighting in Jerusalem during the war does not suggest a description of the situation such as Luke would naturally have alluded to with the same terms. Rather, both authors use the alliteration for literary effect, and there is no compelling reason to believe that Luke is referring to conditions in Jerusalem under siege at this point.

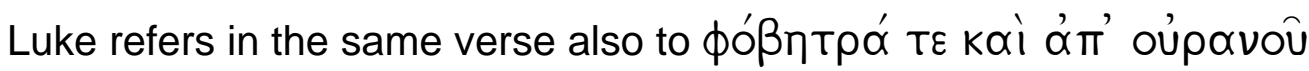
$\sigma \eta \mu \varepsilon \hat{~} \alpha \mu \varepsilon^{\alpha} \alpha^{\prime} \lambda \alpha$. The precise details of these are not specified, but Josephus and Tacitus report a number of phenomena which portended the final investment of Jerusalem and the temple by the Romans (BJ 6:288-89; Hist 5:13; cf Dio, Hist 51.17.5). Irrespective of what historical events may lie behind these accounts, and whether or not Luke knew of them, these phenomena are placed rather earlier in the narrative than would be suggested should this passage be reflecting the fall of Jerusalem in $70 \mathrm{CE}$. If Luke is appropriating a motif from stories surrounding the destruction of Jerusalem, he is quite deliberately distancing such phenomena from the immediate antecedents to the fulfilment of Jesus' prophecy through inserting into the discourse a rather lengthier section on persecution of Christians than is found in Mk 13:9-13.

The section Lk 21:12-19 is by no means simply copied from Mk 13:9-13, although it does envisage much the same range of tribulations to befall Christians. It is widely believed in scholarship that the transmission here is influenced by accounts of persecution in Acts (C F Evans 1990:741). While this section is undoubtedly informed by early Christian experience, much of the detail has no explicit counterpart in Acts. Consideration needs to be given to the possibility that Luke prefers not to report in Acts actual incidences of some of the forms of persecution to which he alludes in this passage, such as betrayal by family and friends (21:16; cf Mk 13:12; 2 Tim 3:2). Nevertheless it cannot be argued that stories are reported in Acts to provide confirmation of the predictions in Lk 21:12-19. While conflict in synagogues is reported in Acts, e g in Jerusalem (6:9) and in Corinth (18:5-6), there is no account in Acts of Christians 


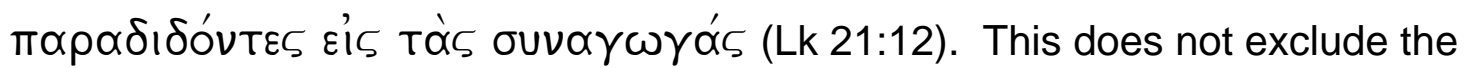
possibility that, in Palestine and in diaspora centres where the Jewish community enjoyed some prestige and influence, Christians deemed responsible for disorder may have been handed over by civic authorities to the local synagogue as the body responsible for order in the Jewish community. While Luke may wish to repudiate any jurisdiction of Jewish politeumae and synagogues over Christians, he nonetheless reports Gallio's ruling that the dispute between Jews and Christians in Corinth was an internal Jewish affair (Ac 18:12-16). We should therefore conclude that Luke has reworked this section in the light of Christian experience of his day (and earlier), reflecting occurrences which are not reported in Acts, either because central characters of that narrative were not directly involved, or because such events would not serve his apologetic purpose. There is nevertheless some degree of historicisation, but not of experiences specific to the war of 66-70 CE in Palestine. On the contrary, it is likely that Christian experience outside Palestine has informed this passage to a greater extent than events in Judaea before, during, or after the war.

It is in the crucial section 21:20-24 that Luke diverges most significantly

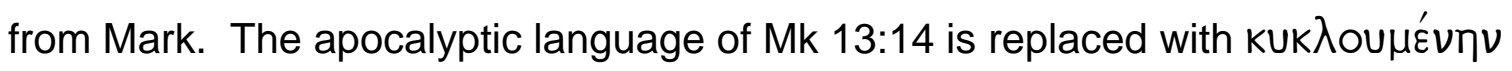

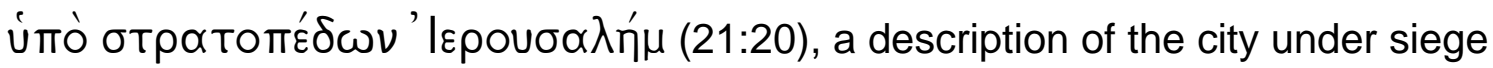
which most scholars attribute to the influence of the closing stages of the war of 66-70 CE (C F Evans 1990:747-48; Fitzmyer 1985:1342-43). The opposite position is argued variously by Dodd (1947) and Manson (1957; cf Robinson 1976:13-30). Dodd points to LXX passages which deal with the destruction of Jerusalem by the Babylonians in $587 \mathrm{BCE}$, and argues that these have inspired Luke, and that there is no reference to the events of 66-70 CE. Fitzmyer concedes the influence of the LXX texts on the wording of this section, but nonetheless maintains that Luke has reworked Mk 13:14-20 in the light of the Roman siege and destruction of Jerusalem in 70 CE (1985:1343). Manson argues that Luke preserves a more ancient form of the tradition, which predated the appropriation of apocalyptic imagery from Daniel at the time of the crisis under Caligula in 40-41 CE. While there is abundant reason to believe that Jesus proclaimed the destruction of the temple (Sanders 1985; Taylor 1999a, 1999c, 
1999d), there is very little, if any, indication that he spoke of the destruction of the entire city. ${ }^{6}$ Nor do the texts which reflect Jesus' prophecy against the temple (Mk 11:15-17; 13:1-2; 14:58; 15:27 and par) suggest that this would be accomplished through military action. This of course does not exclude the possibility that Jesus envisaged the destruction of the temple by Rome, just as Jerusalem had previously been destroyed by the Babylonians. However, the early accrual to this tradition of the motif of rebuilding within three days (Mk 14:58; 15:29; cf Jn 2:19) suggests that supernatural intervention rather than military conquest and destruction may have been envisaged (cf Ac 6:14). This counts against Manson's thesis, and raises questions about Dodd's. The fundamental question is why apocalyptic imagery should have been replaced by Luke with historicising military language. The supposed incomprehensibility of apocalyptic to gentile readers (Fitzmyer 1985:1328) may well be a factor, but seems less than compelling in itself. Luke elsewhere presupposes that at least some readers would recognise allusions to the LXX, so other factors need to be considered. Despite his probable diaspora setting, and gentile as well as Jewish readership and audience, Luke nevertheless refers to Jesus' interlocutors as at least prospective witnesses to these events. While " $1 \delta \eta \tau$... (21:20) is not to be applied by extension to Luke's audience, at least not in a literal sense, it does nonetheless presuppose some degree of comprehension of events of which they would become aware. The description in military terms of the siege of Jerusalem, and its subsequent destruction, emphasises that Jesus' prophecy had been fulfilled, and identifies the action of Titus' forces in 70 CE (BJ 6.130-7.4) as that fulfilment. The LXX allusions to the events of 587 BCE are appropriated precisely because they have been repeated in the events of $70 \mathrm{CE}$, and acquired a new relevance.

It is notable, however, that Luke makes no reference to the destruction of the temple by fire (cf BJ 6.228, 232-66, 407), whether in retrospect or in appropriation of motifs from the fall of Jerusalem to the Babylonians (2 Ki 25:9; 2

${ }^{6}$ Mt 22:7, as discussed above, appear to be a post-70 interpolation into the tradition. Lk 13:35, as also discussed above, is ambiguous, even if dominical in origin. Even if it refers to destruction, this probably not include the entire city. The special Lukan material here and at 19:43-44, already discussed, constitute the only unequivocal reference to the destruction of Jerusalem as a whole as foretold by Jesus. 
Chr 36:19). Destruction by fire is a widespread image of divine judgement in the prophetic tradition (Jr 5:14; 11:16; 15:14; 17:27; 20:9; 21:12, 14; 23:29; Lm 2:3; 4:11; Ezk 10:2, 6; 21:3; 36:5; cf Ps 78:21, 62-63; Q 3:9,17). It would therefore not have been surprising to see some reference to the incineration of the temple, especially if Luke is drawing on allusions to the events of $587 \mathrm{BCE}$ rather than reflecting those of $70 \mathrm{CE}$.

Despite these significant alterations in the tradition, Luke retains much of the material found in Mk 13:14-19. The destruction of Jerusalem is described as

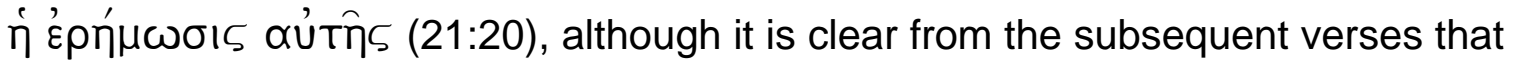
physical devastation is implied, even if sacrilegious acts are included (cf $B J$ 6.316). The injunction to flight before the circumvallation is complete (21:21) is to be distinguished from that in Mk 13:14-16, in that flight is to take place in anticipation of $\dot{\eta}$ ' $\rho \eta_{\mu} \mu \omega \sigma / s$ and not in response to it (Taylor 1996b). Nevertheless the material is derived from Mark (C F Evans 1990:748; Fitzmyer 1985:1342-44). The injunction not to enter the city ahead of the besieging army (21:21) is consistent with that to the inhabitants to flee, but contradicts both the normal practice of rural dwellers withdrawing into walled cities as invading armies devastate the countryside, as indeed happened in Jerusalem before the siege of 68-70 CE (BJ 4.106,135-37,146,490). Furthermore, this injunction reinforces the

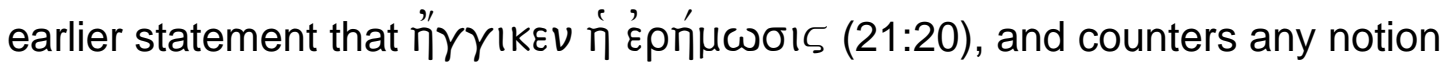
that Jerusalem was inviolable.

The omission of the markan Jesus' injunction to prayer that the time of flight would not fall during winter (13:18) could indicate that this was no longer relevant. Here it is noticeable that, whereas Matthew after the event retains and develops this tradition (24:20), Luke redacts it out of his account as superfluous and obsolete. It should also be noted that Luke's intended readership and audience are less likely to have been directly or even indirectly affected by events in Palestine. Luke retains, and even embellishes, those aspects of the tradition which emphasise fulfilment of Jesus' prophecy, both specifically regarding the fate of Jerusalem and the temple, and more generally of God's judgement upon Israel (C F Evans 1990:746-52; Fitzmyer 1985:1342-47). The 


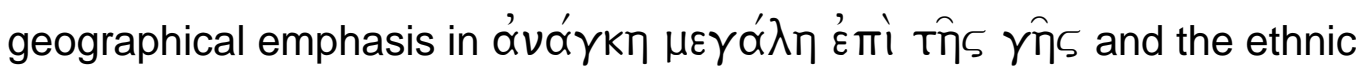

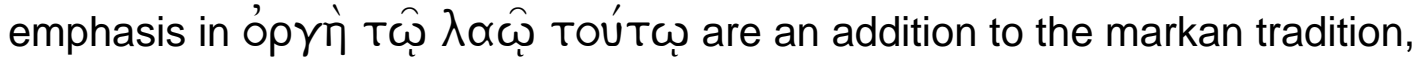
which, as well as enhancing the degree of tribulation referred to, give expression to judgement rather than misfortune as the cause of the events reflected in these verses (cf Brawley 1987; Sanders 1987).

Lk 21:24 concludes this section with further motifs reflecting terrestrial warfare and its aftermath, and is best understood as alluding to events at the conclusion of the war of 66-70 CE. As well as massacre by Roman troops,

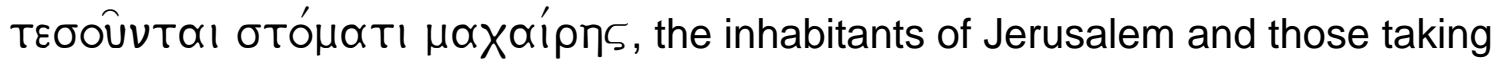

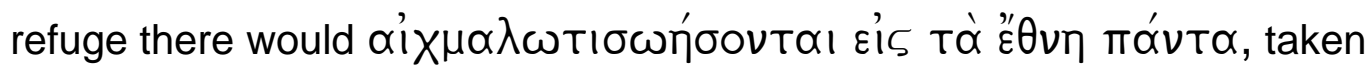
captive, exiled, and enslaved in other lands. While massacre and the enslavement of survivors were the commonplace sequel to sieges, and had followed the destruction of Jerusalem by the Babylonians in 587 BCE (2 Ki 24:11, 18-21), and the motif therefore does not require any specific historical event, substituting apocalyptic speculation with historical prose does not in itself account for this change in the received tradition. Rather, the aftermath of the destruction

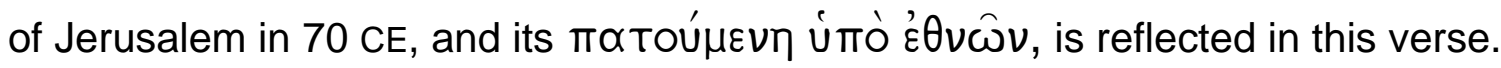

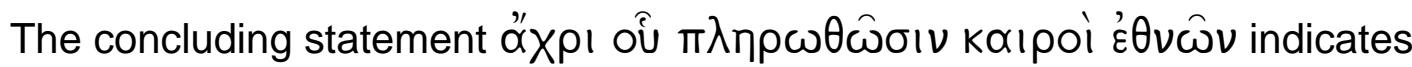
some limit to the duration of gentile domination over Jerusalem and the people of Israel (C A Evans 1990:313; C F Evans 1990:752). This would be a stage in salvation history, which would be curtailed, as the subsequent passage makes clear, by the cosmic events which would climax in the coming of the Son of Man. In a sense, therefore, the notion of a defined era in salvation history which would be characterised by pagan domination is the counterpart to the markan expectation that the time of tribulation would be curtailed by God's final saving act (13:20).

Luke omits the reference to false messiahs and false prophets in $\mathrm{Mk}$ 13:21-23. This can be attributed not only to economy but also to the context in which Luke writes. While prophetic figures emerged from time to time in or from diaspora contexts (BJ 2.261-63; AJ 20.169-72; cf Ezk 1:1), messianic claimants 
are attested only in Palestine, and for the most part in Judaea (BJ 2.55, 61-62; 4.508-10; AJ 17.273-73, 278). The latter would have posed much the greater threat to the allegiance of Christians to the Church, but would not have been encountered in the communities in which Luke-Acts was written and received.

Mark's section on cosmic portents in 13:24-25 is reworked and expanded in Lk 21:25-26. The motif of human responses to these phenomena, ' $\dot{\pi} i \mathrm{~T} \bar{\zeta}$

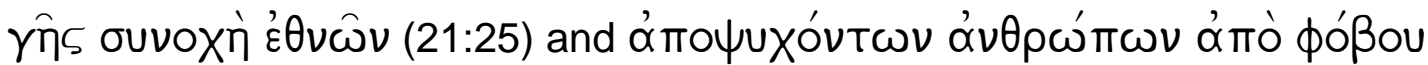
(21:26), complements those of astral and marine turbulence. The inclusion and expansion of these phenomena indicate that Luke is not averse to apocalyptic notions per se. However, there would be nothing cryptic in allusion to ominous events in the cosmos. Nevertheless, it would seem potentially significant that, precisely at the point where Luke moves from historical allusion to future speculation, such apocalyptic motifs should be employed. While the imagery would be recognised universally, and is by no means specific to Judaism (cf Hellholm 1983), still less to apocalyptically oriented Judaism, the change of imagery which coincides with the transition from past to future is nonetheless significant.

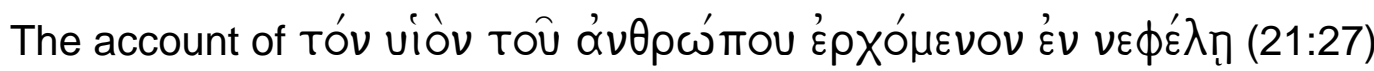
is derived substantially from Mk 13:26. The significant change is that, whereas Mark follows Dn 7:13 in depicting a mass of clouds, ${ }^{7}$ Luke refers to a single cloud, alluding to that in which the shekinah was present with Israel in the wilderness (Ex 13:21-22; 14:19, 24; 16:10; 19:9, 16; 24:15-18; 33:9-10; 34:5; 40:34-38; Lv 16:2; Nm 9:15-22; 10:11, 12, 34; 11:25; 12:5, 10, 14; 14:16, 42; Dt 1:33; 5:22; 31:15; 1 Ki 8:10-11; 2 Chr 5:13-14; Neh 9:12, 19; Job 26:9; 37:15; Ps 78:14; 99:7; 105:39; Ezk 1:4; 10:34), and which is manifest in the lukan narrative at the transfiguration (Lk 9:34) and ascension (Ac 1:9-11) of Jesus (cf C F Evans

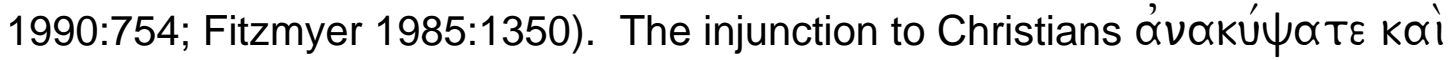

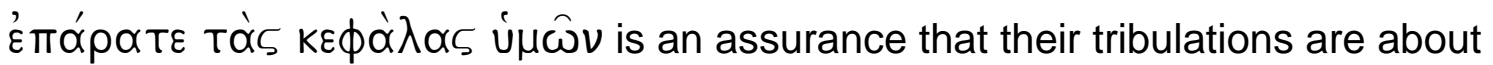
to be reversed (C F Evans 1990:756). Luke omits the gathering of the elect (Mk

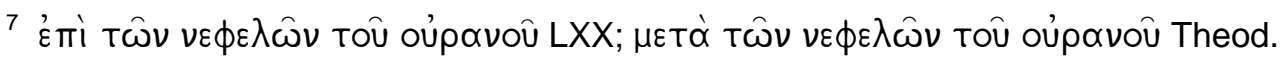


13:27), but includes the $\pi \alpha \rho \alpha \beta \circ \lambda \eta j$ of the fig tree (21:29-31; Mk 13:28-29) and the assurance of the eternity of Jesus' words (21:32-33; Mk 13:30-31). The concluding injunction to vigilance (Mk 13:32-37) is considerably truncated (Lk 21:34-36).

Unlike Matthew, Luke's eschatological discourse reflects considerable development from that found in Mark. The events of 66-70 CE in Palestine, and specifically in and around Jerusalem, have impacted directly and graphically on the transmission of the tradition, despite Luke's geographical and cultural distance from Palestinian Judaism and orientation towards diaspora Jewish and gentile Christians. The fall of Jerusalem and destruction of the temple are presented as fulfilment of Jesus' prophecy, and as inaugurating a new age in salvation history.

\section{CONCLUSION}

We have considered the eschatological discourses in Mt 24 and Lk 21, and found both to be substantially dependent on Mk 13. Their use of the inherited tradition is significantly different, however. Matthew interpolates material from $\mathrm{Q}$ into the discourse, as well as transferring some Markan material to the mission charge, but is otherwise conservative in his transmission of the tradition. No influence of the war of 66-70 CE and the destruction of Jerusalem and the temple can be discerned, despite allusions to those events elsewhere and confidence that Jesus' prophecy of the destruction of the temple would (i e had been) carried out. Luke does not incorporate $\mathrm{Q}$ material into the discourse, but maintains it separately, while substituting some markan material with text derived from an independent source as well as including redactional reworkings of the traditions he has received. Luke reflects very directly the fall of Jerusalem, and interprets this as vindication of Jesus and judgement upon Israel. While Matthew ascribes no eschatological significance to the fall of Jerusalem, for Luke this event inaugurates a new, and penultimate, stage in salvation history. 


\section{Works consulted}

Allison, D C 1998. Jesus of Nazareth: Millenarian prophet. Minneapolis: Fortress.

Bacon, B W 1925. The Gospel of Mark. New Haven: Yale University Press.

Balabanski, V 1997. Eschatology in the making. Cambridge: CUP.

Baltzer, K 1965. The meaning of the temple in the Lukan writings. HTR 58, 263-78.

Beare, F W 1981. The Gospel according to Matthew. Peabody: Hendrickson.

Blenkinsopp, J 1997. Life expectancy in ancient Palestine. SJOT 11, 44-55.

Boring, M E 1991. The continuing voice of Jesus. Louisville: Westminster.

Brawley, R L 1987. Luke-Acts and the Jews. Atlanta: Scholars.

Cohen, S J D 1989. Crossing the boundary and becoming a Jew. HTR 82, 13-33.

Crossan, J D 1988. The cross that spoke. San Francisco: Harper.

Crossan, J D 1991. The historical Jesus. San Francisco: Harper \& Row.

Crossan, J D 1998. The birth of Christianity. Edinburgh: Clark.

Davies, W D \& Allison, D C 1988-97. Matthew. Edinburgh: Clark.

Dodd, C H 1947. The fall of Jerusalem and the "abomination of desolation". JRS 37, 47-54.

Draper, J A 1993. The development of "the sign of the Son of Man" in the Jesus Tradition. NTS 39, 1-21.

Dunn, J D G 1990. Jesus, Paul, and the Law. Louisville: Westminster.

Evans, C A 1990. Luke. Peabody: Hendrickson.

Evans, C F 1990. Saint Luke. London: SCM.

Fitzmyer, J A 1979-1985. The Gospel according to Luke. New York: Doubleday.

Filson, F V 1960. The Gospel according to St Matthew. London: Black.

Gaston, L 1970. No stone on another. Leiden: Brill.

Goodman, M D. 1994. Mission and conversion. Oxford: OUP.

Haenchen, E 1968. Der Weg Jesu. Berlin: De Gruyter.

Hartman, L 1966. Prophecy interpreted. Uppsala: Almqvist \& Wiksell.

Hellholm, D (ed) 1983). Apocalypticism in the Mediterranean world and the Near East. Tübingen: Mohr.

Horsley, R A \& Draper, J A 1999. Whoever hears you hears me: Prophets, performance, and tradition in Q. Harrisburg: TPI.

Hultgren, A J 1979. Jesus and his adversaries. Minneapolis: Augsburg.

Jewett, R 1971. The agitators and the Galatian congregation. NTS 17, 198-212.

McKnight, S 1991. A light among the Gentiles. Minneapolis: Fortress.

Malina, B J \& Rohrbaugh, R L 1991. Social science commentary on the Synoptic Gospels. Minneapolis: Fortress. 
Manson, T W 1957. The sayings of Jesus. London: SCM.

Marshall, I H 1978. Commentary on Luke. Grand Rapids: Eerdmans.

Martin-Achard, R 1962. A light to the nations. Edinburgh: Oliver \& Boyd.

Meier, J P 1994. A marginal Jew, II. New York: Doubleday.

Munck, J 1967. Acts. New York: Doubleday.

Niederwimmer, K 1998. The Didache. Minneapolis: Fortress.

Nolland, J C 1989-93. Luke. Waco: Word.

Räisänen, H 1992. Jesus, Paul and Torah. Sheffield: Sheffield Academic Press.

Reicke, B 1972. Synoptic prophecies on the destruction of Jerusalem, in Aune, D E (ed), Studies in the New Testament and Early Christian literature, 121-34. Leiden: Brill.

Reicke, B 1984. Judaeo-Christianity and the Jewish establishment, A.D. 33-66, in Bammel, E \& Moule, C F D (eds), Jesus and the politics of his day, 145-52. Cambridge: CUP.

Robinson, J A T 1976. Redating the New Testament. London: SCM.

Sanders, E P 1985. Jesus and Judaism. London: SCM.

Sanders, J T. 1987. The Jews in Luke-Acts. London: SCM.

Schweizer, E 1975. Good News according to Matthew. London: SPCK.

Stanton, G N 1992. A Gospel for a new people. Edinburgh: Clark.

Streeter, B H 1930. The four Gospels. London: Macmillan.

Such, W A. 1999. The abomination of desolation in the Gospel of Mark. Lanham: UPA.

Taylor, N H 1996a. Palestinian Christianity and the Caligula crisis, I: Socio-historical reconstruction. JSNT 61, 101-24.

Taylor, N H 1996b. Palestinian Christianity and the Caligula crisis, II: The Markan eschatological discourse. JSNT 62, 13-41.

Taylor, N H 1999a. Prolegomena to reconstructing the eschatological teaching of Jesus. Neotestamentica 33, 145-60.

Taylor, N H 1999b. Luke-Acts and the Temple, in Verheyden, J (ed), The Unity of LukeActs, 409-21. Leuven: Peeters.

Taylor, N H 1999c. Early Christian expectations regarding the return of Jesus. JTSA $104,32-43$.

Taylor, N H 1999d. Jerusalem and the temple in early Christian life and teaching, Neotestamentica 33, 445-61.

Taylor, N H 2000a. Caligula, the church of Antioch, and the Gentile mission. Religion and Theology 7, 1-23. 
Taylor, N H 2000b. Pharisees and Herodians: The political context of Mark 3:6; 12:13, Neotestamentica 34, 299-310.

Taylor, N H 2001a. Popular opposition to Caligula in Jewish Palestine. JSJ 32, 54-70.

Taylor, N H 2001b. The temptation of Jesus on the mountain. JSNT 83, 27-49.

Taylor, N H 2002. Who persecuted the Thessalonian Christians? HTS 58, 784-801.

Taylor, N H 2003a. Paul and the historical Jesus quest. Neotestamentica 37. (Forthcoming).

Taylor, N H 2003b. Stephen, the temple, and early Christian eschatology. Revue Biblique 110, 62-85.

Taylor, V 1926. Behind the Third Gospel. Oxford: Clarendon.

Theissen, G 1991. The Gospels in context. Minneapolis: Fortress.

Wright, N T 1992. The New Testament and the people of God. Minneapolis: Fortress. 